\title{
25 Research Soure \\ Edge function in patchy mussel bed habitats: variation across nearby rocky shore sites
}

\section{Sabrina Andrea Soria ( $\nabla$ sasoria@macn.gov.ar)}

Museo Argentino de Ciencias Naturales Bernardino Rivadavia https://orcid.org/0000-0002-8031-1882

\section{Jorge Luis Gutiérrez}

IIMYC: Instituto de Investigaciones Marinas y Costeras

Juliana Andrea Gonzalez

Museo Argentino de Ciencias Naturales Bernardino Rivadavia

\section{Sofía Luz Callá}

Museo Argentino de Ciencias Naturales Bernardino Rivadavia

\section{María Gabriela Palomo}

Museo Argentino de Ciencias Naturales Bernardino Rivadavia

\section{Research Article}

Keywords: waves, predators, extreme temperatures, algal production, composition, dynamics

Posted Date: June 3rd, 2021

DOl: https://doi.org/10.21203/rs.3.rs-540112/v1

License: (c) (i) This work is licensed under a Creative Commons Attribution 4.0 International License. Read Full License 


\section{Abstract}

Mussels form dense three-dimensional beds that serve as habitat to other species. In rocky shores, these beds are often interspersed by gaps due to patchy dislodgement/mortality caused by the action of waves, predators, and/or extreme temperatures. Although mussel patches and gaps are known to support distinctive invertebrate communities, variations in invertebrate habitat function between the interior and edges of mussel patches and gaps were not yet examined. Here, we evaluated variations in habitat properties and invertebrate composition between the edge and interior of mussel (Brachidontes rodriguezii) patches and gaps at three rocky shore sites in the Southwestern Atlantic. Our results indicate that the interior and edge of mussel patches differ in terms of mussel size and density (i.e., a surrogate of habitat structure) and the amount of sediments they accumulate. However, this does not directly translate into consistent differences on temperature, desiccation, and invertebrate composition across sites. As it concerns to gaps, we generally observed increased limpet (Siphonaria lesonii) densities at their edges, which suggests that they encounter favourable conditions by the perimeter of mussel patches. The lack of consistent edge effects on the invertebrates of mussel patches suggests that their species composition would remain largely unaffected by expected increases in gap and edge habitat formation due to ongoing increases in the frequency and magnitude of storms and heat waves. Yet, if increased availability of edge habitats leads to increased overall density of limpets in these rocky shores, then changes could be expected in algal production, composition, and dynamics.

\section{Introduction}

Foundation species are species or groups of functionally similar taxa that by virtue of their size and/or abundance form much of the physical structure of the habitat (e.g., trees in forests, mussels in mussel beds, corals in coral reefs; Dayton 1972; Ellison et al. 2005; Ellison 2019). In doing so, they determine the diversity of associated taxa primarily through non-trophic interactions (i.e., physical ecosystem engineering; sensu Jones et al. 1994, 1997; see Ellison 2019). For instance, the dense three-dimensional beds formed by intertidal mussels provide other species with attachment surfaces as well as interstitial spaces where water flow is attenuated, sediments become trapped, and the impacts of predators, extreme temperatures, and desiccation are all reduced (Gutiérrez et al. 2003, 2011). Through these non-trophic, engineering mechanisms mussels facilitate other species and often lead to increased overall invertebrate abundance and richness in rocky shores (e.g., Suchanek 1985; Tokeshi and Romero 1995; Borthagaray and Carranza 2007; Silliman et al. 2011; Bagur et al. 2016).

On the other hand, mussel cover is usually discontinuous in rocky shores as gaps form due to patchy dislodgement/mortality caused by the action of waves, predators, and/or extreme temperatures (see Paine 1966; Dayton 1971; Paine and Levin 1981; Sousa 1984; Mislan and Whethey 2015). Differences in the abundance and composition of invertebrate assemblages between gaps mussel-covered patches have been largely documented in rocky shores (e.g., Suchanek 1985; Tokeshi and Romero 1995; Borthagaray and Carranza 2007; Bagur et al. 2016). Yet, variation in habitat attributes and invertebrate composition within mussel patches have seldom been examined in these systems. Jurgens and Gaylord (2016) compared the thermal regime and the exposure of juvenile mussels to detrimental temperatures across the vertical profile of thick (12 cm depth), multi-layered mussel beds. However, horizontal variations in invertebrate habitat function between the interior and edges of patches were not yet examined, even when such edge effects proved to be important in patches of other marine foundation species (e.g., seagrass, Tanner 2005; mangroves, Amortegui-Torres et al. 2013; kelp, Arkema and Samhouri 2019). Evaluating edge effects in patchy mussel beds is relevant in view of forecasted increases in the 
frequency and magnitude of extreme events such as storms and heat waves (Harley et al. 2006; Byrnes et al. 2011; Oliver et al. 2018), which will likely enhance rates of mussel dislodgement and mortality with concomitant increases in mussel bed patchiness and the relative proportion of edge habitats.

Here, we evaluate variations in habitat properties and invertebrate composition between the edge and interior of mussel-covered areas and gaps at three nearby rocky shore sites in the Southwestern Atlantic. The mussel Brachidontes rodriguezii (d'Orbigny, 1842) is the dominant species in the mid intertidal zone at these sites, where it forms dense (up to 2000 ind $\mathrm{m}^{-2}$ ) and primarily single-layered beds interspersed by gaps (see Penchaszadeh et al. 2007; Arribas et al. 2015; Gutiérrez et al. 2015; 2018). B. rodriguezii beds trap sediments and modulate extreme temperatures and desiccation during the low tide (Arribas et al. 2013; Gutiérrez et al. 2019). Yet, mussels in the edge and interior of patches differ in their position relative to the substrate (anteroposterior axis parallel to the substrate in the edge of patches and perpendicular to the substrate in their interior; pers. comm.). Additionally, we had preliminarily observed a trend toward an increased proportion of larger mussels in the interior of patches, at least in some sites. Differences in mussel position and size between mussel patch edges and interiors could translate into differences in the ability of mussels to retain sediments and modulate the temperature and desiccation levels experienced by other organisms. As it concerns to the gaps without mussels, we posit that the mussels at their perimeter might make gap edges more benign that their interiors as regards to microclimate (e.g., shading effects on temperature and moisture) and hydrodynamics (e.g., shielding from water flows), which may potentially favor other invertebrates (e.g., limpets; see Dayton 1971; Sousa 1984; Tanaka and Magalhães 2002).

Based on the above observations and predictions, here we investigate (a) the biomass, density, and size of mussels in the interior and edge of their patches (i.e., as surrogates of mussel bed structure), (b) the sediments trapped in the interior and edge of mussel patches, (c) temperature and desiccation in the interior and edge of mussel patches and gaps and, (d) the identity and abundance of invertebrates in the interior and edge of the mussel patches and gaps.

\section{Material And Methods}

\section{Study site and sampling design}

This study was conducted at three nearby rocky shore sites in Buenos Aires province, Argentina, namely: Playa

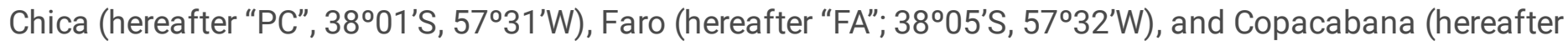
"CO"; 38 $14^{\circ} \mathrm{S}, 57^{\circ} 46^{\prime} \mathrm{W}$ ). The three sites are located within a ca. $40 \mathrm{~km}$ coastal range between the cities of Mar del Plata and Miramar. The substrates at these sites are orthoquartzite (PC and FA) and consolidated Pampean loess cemented with calcium carbonate (CO) (Gutiérrez et al. 2018). Tides along this area are semidiurnal and microtidal (0.83 m mean amplitude, Servicio de Hidrografía Naval, www.hidro.gov.ar).

Mussel patches and gaps were sampled in the horizontal surfaces at the mid intertidal zone of these sites (i.e., the level occupied by mussel beds; see Introduction). The edge and interior (hereafter "Positions") of mussel patches and gaps were defined as follows (see Fig. 1). In mussel patches, edge was defined as the $6 \mathrm{~cm}$ fringe by their perimeter where mussels are predominantly positioned with their anteroposterior axis parallel to the substrate whereas the interior was considered as the area within the mussel patches at least $10 \mathrm{~cm}$ from its perimeter where virtually all mussels are positioned with their anteroposterior axis perpendicular to the substrate. Analogously, the edge in gaps was defined as the $6 \mathrm{~cm}$ fringe adjacent to the mussel bed perimeter and the gap 
interior was considered as the area located at least $10 \mathrm{~cm}$ from the mussel bed perimeter. Edges and interiors were sampled from different mussel patches/gaps to ensure sample independence.

\section{Mussel biomass, density, and size}

On January 2017, squared mussel beds samples ( $5 \mathrm{~cm}$ side) were taken from the edge and interior of mussel patches with the aid of a putty knife (six replicates each). Samples were preserved in alcohol $96 \%$ and taken to the lab, where mussels were sorted from sediments and other organisms and then oven-dried $\left(60^{\circ} \mathrm{C}\right.$ during $\left.15 \mathrm{~h}\right)$. After drying, the mussels were weighed $(0.01 \mathrm{~g}$ precision) and counted to respectively calculate their biomass and density per sample. Fifty mussels were then taken at random from each sample and measured along their anteroposterior axis using a digital caliper (0.01 $\mathrm{mm}$ precision).

Variations in mussel biomass were evaluated with a linear model with Position and Site as factors and a variance structure since data was heteroscedastic (package nlme in R; Pinheiro et al. 2019; R Core Team 2020). Variations in the density of mussels were evaluated with a generalized linear model (negative binomial distribution and log link function) with Sites and Position as factors. We used a negative binomial distribution as our data were counts showing overdispersion (Allison 2012). Model parameters were estimated with maximum likelihood method using package MASS in R (Venables and Ripley 2002; R Core Team 2020). Differences between Positions at each Site were evaluated with planned Tukey tests using the emmeans package with $R$ (Lenth 2019; R Core Team 2020). Finally, differences in the size-frequency distributions of mussels between the interior and edges of patches at each Site were evaluated using Kolmogorov-Smirnov tests (Zar 1984; $n=300)$.

\section{Sediment trapped in mussel patches}

The sediment retained within edge and interior of mussel patches was quantified from the same samples collected for invertebrate analysis in December 2014 (see Invertebrate composition and density). Twenty rectangular samples $(6 \times 12 \mathrm{~cm})$ were taken from the interior and edge of mussel patches with the aid of a putty knife. In edge samples, the longer side of the rectangle was placed parallel to the patch perimeter (see Invertebrate composition and density, for rationale behind the choice of sample shape and dimensions). Samples were preserved in alcohol $96 \%$ and then sieved in the laboratory with 500 and $62 \mu \mathrm{m}$ meshes to separate sediment particles from mussels and other macrofauna. The sediments collected in both sieves were pooled, oven-dried $\left(70^{\circ} \mathrm{C}\right.$ during 24 hours) and weighed ( $0.0001 \mathrm{~g}$ precision). The sediments smaller than $62 \mu \mathrm{m}$ (silt and clay) were not included in the analysis as they make a minor fraction of the sediment mass in these shores (pers. comm.).

Variations in the dry weight of sediments trapped in the edge and interior of mussel beds were evaluated with a linear model with Position and Site as factors and a variance structure since data was heteroscedastic (package nlme in R; Pinheiro et al. 2019; R Core Team 2020).

\section{Desiccation and temperature}

The ability of mussel beds to reduce desiccation during air exposure was evaluated at the three sites on December 6,2017 . This was a sunny, hot day (maximum temperature: $31^{\circ} \mathrm{C}$ ). The mid intertidal zone in that date become air exposed around 1:00 PM (the minimum low tide occurred at 4:39 p.m.). Desiccation was quantified as water loss from absorbent cloth pre-wetted in seawater. Absorbent cloth pads $(6 \times 6 \mathrm{~cm}, \mathrm{n}=5)$ were placed under the mussel layer in the edge and interior of mussel patches, and on the rock surface in the edge and interior of gaps. To place the cloth pads under the mussel layer a portion of that layer was removed with a putty knife, 
the cloth piece was placed on the exposed rock surface, and the portion of the mussel layer returned to its original position covering the pad. Pre-wetted absorbent cloth pads were weighed right before deployment (1:40 p.m., same hour at the three sites) and retrieved and weighed again 2 hours later $(0.01 \mathrm{~g}$ precision). Desiccation was expressed as percent water loss from the absorbent over the study period. Differences in desiccation between Positions and Sites were analysed with beta regression (logit link function) using the betareg package in R (Cribari-Neto and Zeileis 2010; R Core Team 2020). Differences between Positions at each site were evaluated with planned Tukey tests using the emmeans package with R (Lenth 2019, R Core Team 2020).

Temperatures in the edge and interior of mussel patches and gaps were measured at $\mathrm{CO}$ on March 31, 2019, during a midday low tide ( $24^{\circ} \mathrm{C}$ maximum temperature; minimum low tide at 11:06). Temperature was recorded every minute from 10:45 a.m. to 2:20 p.m. using data loggers (Hobo MX2201 and UA-001-64; 4 loggers per Position). The loggers in mussel patches were placed under the mussel layer while those in gaps were placed directly on the rock surface. To place the loggers under the mussel layer a portion of that layer was first removed with a putty knife. Then, a hole of the size of the logger was made in the rock and the logger inserted into the hole with their top surface flushing with the rock surface. Finally, the portion of the mussel layer was placed again in its original position covering the hole with the logger. Loggers were placed in holes to avoid altering the elevation and topography of the mussel layer. Measurements were made only in $\mathrm{CO}$ because we lacked sufficient loggers to simultaneously repeat them at the two other sites. Additionally, this site shows a relatively soft substrate (cf. hard quartizitic rock at the two other sites; see Study site and sampling design), which made easier to make holes for the placement of loggers. Differences in the maximum and minimum temperature between Positions were evaluated with linear models. Differences between Positions were evaluated with Tukey tests using the emmeans package with R (Lenth 2019; R Core Team 2020).

\section{Invertebrate composition and density}

Invertebrates in the edge and interior of mussel patches and gaps were sampled at every site on February, May. August, and December 2014 (i.e., summer, autumn, winter, and spring, respectively; $n=10$ ). The samples from mussel patches were rectangular $(6 \times 12 \mathrm{~cm})$ portions of the mussel layer that were removed with a putty knife. We opted for that kind sampling unit as they can be fit within the edge of the mussel bed (i.e., with their longer side parallel to the perimeter of the mussel patch) and approximates the area of the cylindrical core that is the standard to sample mussel bed invertebrates at these sites (i.e., $10 \mathrm{~cm}$ diameter core; see, Palomo et al. 2016; Gutiérrez et al. 2019; Arribas et al. 2019). These samples were fixed in $96 \%$ alcohol, sieved in the lab with a 500 $\mu \mathrm{m}$ mesh, and invertebrates identified and quantified under stereoscopic microscope. Samples from gaps were taken with equal-sized $(6 \times 12 \mathrm{~cm})$ rectangular frames (edge samples taken with the longer side of the frame adjacent to the gap perimeter). The invertebrates in gap samples were identified and quantified in the field. All organisms were identified to the lowest possible taxonomic level. Assemblage structure was compared among Positions using permutational multivariate analysis of variance (PERMANOVA) of Bray-Curtis dissimilarities (PRIMER program; Clarke 1993) and a non-metric multidimensional scaling (nMDS) of Manhattan dissimilarities was done to visualize the possible differences (PAST software; Hammer et al. 2001). Furthermore, differences in the number of invertebrate species per sample (i.e., species density; see Underwood et al. 2008 were analysed using a generalized linear model with Position, Site and Season as fixed effects explanatory variables. A ConwayMaxwell Poisson distribution and log link function were used in this case because the data showed subdispersion. Differences in the densities of common species (those present at all Sites and showing mean overall densities over one individual per sample) were evaluated with generalized linear models using a negative 
binomial distribution and a log link function since data showed overdispersion in all cases (Allison 2012). All generalized linear models were done using the MASS package with R (Venables and Ripley 2002; R Core Team 2020). Differences between Positions were evaluated with planned Tukey tests using the emmeans package with R (Lenth 2019; R Core Team 2020).

\section{Results}

\section{Mussel biomass, density, and size}

Mussel biomass was higher in the interior than the edge of patches at the three sites (Table 1, Fig. 2a) but mussel density was always lower in the interior than in the edge of patches (Table 1, Fig. 2b), which indicates the presence of larger mussels in the interior of patches. Accordingly, mussel size-frequency distributions significantly differed between patch edges and interiors at the three sites (Kolmogorov-Smirnov tests, Dmax = $0.103,0.123$, and 0.09 at PC, FA y CO, respectively, $n=300, P<0.05$ in all cases; Figs. 2c-e). A higher proportion of larger mussels was found in the interior than in the edge of mussel patches (Figs. 2c-e).

\section{Sediment trapped in mussel patches}

A higher amount of sediment was retained in the interior than in the edge of mussel patches across the three sites (Table 1, Fig. 3).

Table 1 Analysis of deviance for linear model relating mussel biomass and sediment weight and generalized linear model relating mussel density between Positions (interior and edge of mussel patches and gaps) and Sites (Playa Chica, Faro, and Copacabana). Asterisks indicate significant effects

\begin{tabular}{|clllll|}
\hline & $\chi^{2}$ & df & \multicolumn{1}{l|}{} & \\
\hline Mussel biomass & & & & \\
\hline Site & 208.58 & 2 & $<0.001$ & $*$ \\
\hline Position & 6.74 & 1 & $<0.001$ & $*$ \\
\hline Site: Position & 2.95 & 2 & 0.228 & \\
\hline Mussel density & & & & \\
\hline Site & 127.44 & 2 & $<0.001$ & $*$ \\
\hline Position & 12.10 & 1 & $<0.001$ & $*$ \\
\hline Site: Position & 1.33 & 2 & 0.513 & \\
\hline Sediments retained & & & & \\
\hline Site & 11.34 & 2 & 0.003 & $*$ \\
\hline Position & 14.35 & 1 & $<0.001$ & $*$ \\
\hline Site: Position & 1.77 & 2 & 0.555 & \\
\hline
\end{tabular}


Desiccation showed different patterns across Positions at each Site (Table 2, Fig. 4). Yet, evidence of edge effects was only found at FA where mussel patch interiors showed lower desiccation relative to gaps (edge and interior indistinctly), and mussel patch edges did not differ from both of the above (Fig. 4). Lower desiccation was observed in mussel patches relative to gap in PC, but no difference was found between edges and interiors both in mussel patches and gaps (Fig. 4). Finally, there were no differences in desiccation between all four positions at CO (Fig. 4).

Table 2 Analysis of deviance for beta regression model relating desiccation (as percent water loss from prewetted absorbent cloth pads) with Positions (interior and edge of mussel patches and gaps) and Sites (Playa Chica, Faro, and Copacabana). Asterisks indicate significant effects

\begin{tabular}{|lllll|}
\hline & $\chi^{2}$ & df & $\boldsymbol{p}$ & \\
\hline Site & 1.19 & 3 & 0.755 & \\
\hline Position & 20.35 & 2 & $<0.001$ & $*$ \\
\hline Site: Position & 32.7 & 6 & $<0.001$ & $*$ \\
\hline
\end{tabular}

Maximum and minimum temperatures did not differ between the interior and edge of mussel patches nor between the interior and edge of gaps (Fig. 5). Maximum and minimum temperatures underneath the mussel bed were $5-6{ }^{\circ} \mathrm{C}$ lower than those on gaps (Table 3, Fig. 5).

Table 3 Analysis of variance for linear model relating the maximum and minimum temperature between Positions (i.e., interior and edge of mussel patches and gaps) in Copacabana. Asterisks indicate significant effects

\begin{tabular}{|llllll|}
\hline & Source of variation & MS & df & $\boldsymbol{F}$ & $\boldsymbol{p}$ \\
\hline Max. temperature & & & & & \\
& Position & 43.16 & 3 & 69.52 & $0.005 *$ \\
& Residual & 6.21 & 12 & & \\
Min. temperature & & & & & \\
& Position & 40.93 & 3 & 70.83 & $0.005 *$ \\
& Residual & 5.78 & 12 & & \\
\hline
\end{tabular}

\section{Invertebrate composition and density}

Twenty invertebrate taxa were collected in the samples (see Table 4). In mussel patches, the most abundant species were the pulmonate limpet Siphonaria lessonii, followed by the barnacle Balanus glandula and polychaetes Syllis spp. and Boccardia polybranchia. Most of the species sampled in mussel patches were found both in their edges and their interiors, except for some species that occurred at low densities (less 3 individuals 
across all samples) and were only found at the edges (see Table 4). S. lessonii and B. glandula were the only invertebrate species found in gaps.

The effect of Position on invertebrate assemblage composition varied across Sites and Seasons in an inconsistent fashion (i.e., a significant second-order interaction was observed between exploratory explanatory variables; Table 5, Fig. 6). Similar results were obtained for species density (Table 6, Fig. 7a) as well as the densities of Siphonaria lessonii and Balanus glandula (Table 6). S. lessonii densities were commonly higher in the edge than the interior of gaps and generally similar between the edge and interior of mussel patches (but see spring samples from CO; Fig. 7b). B. glandula densities were generally higher in gaps than in mussel patches but usually did not differ between edge and interiors both in mussel patches and gaps (exceptions were the autumn samples from PC and winter samples from FA; Fig. 7c).

Table 4 List of taxa found in the samples. Abbreviation corresponds to the different Positions (MI: Mussel Interior, ME: Mussel Edge, GI: Gap Interior, GE: Gap Edge). The underlined crosses indicate species with less than four individuals found at each Position and Site 


\begin{tabular}{|c|c|c|c|c|c|c|c|c|c|c|c|c|c|}
\hline \multirow[t]{2}{*}{ Species } & \multirow[t]{2}{*}{ Taxa } & \multicolumn{4}{|c|}{ Playa Chica } & \multicolumn{4}{|c|}{ Faro } & \multicolumn{4}{|c|}{ Copacabana } \\
\hline & & MI & ME & GE & GI & MI & ME & GE & GI & MI & ME & GE & GI \\
\hline $\begin{array}{l}\text { Siphonaria } \\
\text { lessonii }\end{array}$ & $\begin{array}{l}\text { Mollusca } \\
\text { Gastropoda }\end{array}$ & $\mathrm{x}$ & $\mathrm{x}$ & $x$ & $\mathrm{x}$ & $\mathrm{x}$ & $x$ & $\mathrm{x}$ & $x$ & $\mathrm{x}$ & $\mathrm{x}$ & $x$ & $x$ \\
\hline $\begin{array}{l}\text { Balanus } \\
\text { glandula }\end{array}$ & $\begin{array}{l}\text { Crustacea } \\
\text { Decapoda }\end{array}$ & $x$ & $x$ & $x$ & $x$ & $\mathrm{x}$ & $x$ & $\mathrm{x}$ & $x$ & $\mathrm{x}$ & $\mathrm{x}$ & $x$ & $x$ \\
\hline $\begin{array}{l}\text { Hyale } \\
\text { grandicornis }\end{array}$ & $\begin{array}{l}\text { Crustacea } \\
\text { Amphipoda }\end{array}$ & $x$ & $x$ & & & $x$ & $x$ & & & $x$ & & & \\
\hline $\begin{array}{l}\text { Monocorophium } \\
\text { sp. }\end{array}$ & $\begin{array}{l}\text { Crustacea } \\
\text { Amphipoda }\end{array}$ & $\underline{x}$ & $\underline{x}$ & & & & $\underline{x}$ & & & & & & \\
\hline $\begin{array}{l}\text { Tanaidacea } \\
\text { indet. }\end{array}$ & $\begin{array}{l}\text { Crustacea } \\
\text { Tanaidacea }\end{array}$ & & & & & $\mathrm{x}$ & $x$ & & & & & & \\
\hline $\begin{array}{l}\text { Sphaeroma } \\
\text { serratum }\end{array}$ & $\begin{array}{l}\text { Crustacea } \\
\text { Isopoda }\end{array}$ & $x$ & $x$ & & & $x$ & $x$ & & & & & & \\
\hline Idotea balthica & $\begin{array}{l}\text { Crustacea } \\
\text { Isopoda }\end{array}$ & $\underline{x}$ & $\underline{x}$ & & & & & & & & & & \\
\hline $\begin{array}{l}\text { Halosydnella } \\
\text { australis }\end{array}$ & $\begin{array}{l}\text { Annelida } \\
\text { Polychaeta }\end{array}$ & $x$ & & & & & $x$ & & & & $\mathrm{x}$ & & \\
\hline Syllis gracilis & $\begin{array}{l}\text { Annelida } \\
\text { Polychaeta }\end{array}$ & $\mathrm{x}$ & $\mathrm{x}$ & & & $\mathrm{x}$ & $x$ & & & $\mathrm{x}$ & & & \\
\hline Syllis spp. & $\begin{array}{l}\text { Annelida } \\
\text { Polychaeta }\end{array}$ & $x$ & $\mathrm{x}$ & & & $x$ & $x$ & & & $\mathrm{x}$ & $x$ & & \\
\hline Nereididae sp. & $\begin{array}{l}\text { Annelida } \\
\text { Polychaeta }\end{array}$ & $\underline{x}$ & $\underline{x}$ & & & $x$ & $x$ & & & $x$ & $x$ & & \\
\hline $\begin{array}{l}\text { Boccardia } \\
\text { polybranchia }\end{array}$ & $\begin{array}{l}\text { Annelida } \\
\text { Polychaeta }\end{array}$ & $\underline{x}$ & $\underline{x}$ & & & $x$ & $x$ & & & $x$ & $x$ & & \\
\hline $\begin{array}{l}\text { Protoariciella } \\
\text { sp. }\end{array}$ & $\begin{array}{l}\text { Annelida } \\
\text { Polychaeta }\end{array}$ & $x$ & $\mathrm{x}$ & & & $\mathrm{x}$ & $\mathrm{x}$ & & & & & & \\
\hline Caulleriella sp. & $\begin{array}{l}\text { Annelida } \\
\text { Polychaeta }\end{array}$ & & $\underline{x}$ & & & & & & & & & & \\
\hline Capitella sp. & $\begin{array}{l}\text { Annelida } \\
\text { Polychaeta }\end{array}$ & & $\underline{x}$ & & & & & & & & & & \\
\hline Nemertea indet. & Nemertea & $x$ & $\mathrm{x}$ & & & $x$ & $\mathrm{x}$ & & & $x$ & $x$ & & \\
\hline Actiniaria indet. & $\begin{array}{l}\text { Cnidaria } \\
\text { Anthozoa }\end{array}$ & & $\underline{x}$ & & & $x$ & & & & & & & \\
\hline $\begin{array}{l}\text { Chironomidae } \\
\text { sp. }\end{array}$ & Insecta Diptera & $x$ & $x$ & & & $x$ & $x$ & & & $x$ & $x$ & & \\
\hline $\begin{array}{l}\text { Pachycheles } \\
\text { laevidactylus }\end{array}$ & $\begin{array}{l}\text { Crustacea } \\
\text { Decapoda }\end{array}$ & & $\underline{x}$ & & & & & & & & & & \\
\hline Ammotheidae & $\begin{array}{l}\text { Insecta } \\
\text { Pycnogonida }\end{array}$ & & $\underline{x}$ & & & & & & & & & & \\
\hline
\end{tabular}


Table 5 PERMANOVA testing the effect of Positions (i.e., interior and edge of mussel patches and gaps), Sites (Playa Chica, Faro, and Copacabana) and Seasons (Summer, Autumn, Winter and Spring) on invertebrate assemblage composition. Asterisks indicate significant effects

\begin{tabular}{|llllll|}
\hline & Source of variation & MS & df & $\boldsymbol{F}$ & $\boldsymbol{p}$ \\
\hline Max. temperature & & & & & \\
& Position & 43.16 & 3 & 69.52 & 0.005 * \\
\hline Min. temperature & Residual & 6.21 & 12 & & \\
\hline & & & & & \\
\hline & Position & 40.93 & 3 & 70.83 & 0.005 * \\
& Residual & 5.78 & 12 & & \\
\hline
\end{tabular}

As for the taxa that exclusively occurred in mussel patches, the most common were the polychaetes Syllis spp. and Boccardia polybranchia, and the larvae/pupae of Chironomidae. Syllis spp. densities were higher in the edge than in the interior of mussel beds at some Sites and Seasons (Table 6, Fig. 8a). The densities of B. polybranchia did not differ between the interior and edge of mussel patches in all the Sites and Seasons (Table 6, Fig. 8b). Chironomid densities did not generally differ between the interior and edge of mussel patches across Sites and Seasons (the sole exception were the spring samples at $\mathrm{CO}$, which showed increased densities in the interior of mussel patches relative to edges; Table 6, Fig. 8c).

Table 6 Analysis of deviance for generalized linear models relating species density (i.e., number of species per sample) and the density of common species (i.e., those present at all Sites and showing mean overall densities over one individual per sample) between Positions (i.e., interior and edge of mussel patches and gaps), Sites (Playa Chica, Faro, and Copacabana) and Seasons (Summer, Autumn, Winter and Spring). Asterisks indicate significant effects 


\begin{tabular}{|c|c|c|c|c|c|}
\hline & & $x^{2}$ & df & $p$ & \\
\hline \multicolumn{6}{|l|}{ Species density } \\
\hline & Site & 70.23 & 2 & $<0.001$ & * \\
\hline & Position & 788.71 & 3 & $<0.001$ & * \\
\hline & Seasons & 97.86 & 3 & $<0.001$ & * \\
\hline & Site:Position & 30.47 & 6 & $<0.001$ & * \\
\hline & Site: Seasons & 65.74 & 6 & $<0.001$ & * \\
\hline & Position: Seasons & 77.69 & 9 & $<0.001$ & * \\
\hline & Site:Position: Seasons & 53.58 & 18 & $<0.001$ & * \\
\hline \multicolumn{6}{|c|}{ Siphonaria lessonii } \\
\hline & Site & 554.6 & 2 & $<0.001$ & * \\
\hline & Position & 90.87 & 3 & $<0.001$ & * \\
\hline & Seasons & 202.03 & 3 & $<0.001$ & * \\
\hline & Site:Position & 76.73 & 6 & $<0.001$ & * \\
\hline & Site: Seasons & 63.78 & 6 & $<0.001$ & * \\
\hline & Position:Seasons & 133.6 & 9 & $<0.001$ & * \\
\hline & Site:Position:Seasons & 64.16 & 18 & $<0.001$ & * \\
\hline \multicolumn{6}{|l|}{ Balanus glandula } \\
\hline & Site & 137.25 & 2 & $<0.001$ & * \\
\hline & Position & 279.84 & 3 & $<0.001$ & * \\
\hline & Seasons & 7.491 & 3 & 0.058 & \\
\hline & Site:Position & 17.86 & 6 & 0.006 & * \\
\hline & Site: Seasons & 28.47 & 6 & $<0.001$ & * \\
\hline & Position:Seasons & 24.28 & 9 & 0.003 & * \\
\hline & Site:Position:Seasons & 29.99 & 18 & 0.037 & * \\
\hline \multicolumn{6}{|l|}{ Syllis spp. } \\
\hline & Site & 98.419 & 2 & $<0.001$ & * \\
\hline & Seasons & 60.856 & 3 & $<0.001$ & * \\
\hline & Position & 7.561 & 1 & 0.006 & * \\
\hline & Site: Seasons & 58.380 & 6 & $<0.001$ & * \\
\hline
\end{tabular}




\begin{tabular}{|lllll|}
\hline & Site:Position & 3.704 & 2 & 0.157 \\
& Position:Seasons & 7.437 & 3 & 0.059 \\
& Site:Position:Seasons & 11.337 & 6 & 0.078 \\
Chironomidae larvae-pupae & & & & \\
\hline & & & & \\
\hline & Site & 6.55 & 2 & 0.037
\end{tabular} *

\section{Discussion}

In summation, our results indicate that the interior and edge of mussel patches differ in terms of habitat structure (i.e., higher mussel biomass, lower density, and larger individuals in the interior; also differences in the prevailing position of mussels relative to the substrate, see Introduction) and the amount of sediments they accumulate within the mussel matrix (i.e., higher in the interior). These differences, however, do not directly translate into differences in temperature (i.e., similar between interior and edge), desiccation (i.e., differences observed at one out of the three sites), and invertebrate composition (i.e., inconsistent patterns across sites and seasons). In agreement, differences in the abundance of some common taxa between the edge and interior of patches were inconsistently observed across sites and seasons (e.g., Balanus glandula) or not observed at all (e.g., Boccardia polybranchia). On the other hand, the edge and interior of gaps did not differ as regards to temperature and desiccation, but frequently differed in limpet (Siphonaria lessonii) densities (i.e., higher at the edge of gaps). This suggests that gap edges have emergent properties of which limpets can take advantage, aside from the observed lack of differences in temperature and desiccation between gap edges and interiors. 
Although differences in mussel size, density, and biomass between the edge and interior of mussel patches suggest differences in packing and space available to interstitial invertebrates (e.g., polychaetes, amphipods, isopods), there were no consistent differences in the taxonomic composition of invertebrate assemblages between mussel bed edges and interiors across sites and/or seasons, nor consistent differences in the abundance of common invertebrate taxa. This suggests that structural differences between mussel bed edges and interiors are not large enough to be relevant to invertebrates (cf. previous studies comparing morphologically different mussel species or those where mussel size and clumping were manipulated to produce sharp differences in mussel bed structure; e.g., Palomo et al. 2007; Gestoso et al. 2013). Similarly, although sediment availability was higher in the interior of mussel beds, there were no differences in the density of sedimentdependent species, such as the polychaete Boccardia polybranchia. This means that mussel patch edges and interiors show comparable habitat quality for invertebrates in spite of differences in three-dimensional structure and sediment availability. The general lack of differences in invertebrate composition and density between the edge and interior of mussel beds is in line with recent findings by Bertolini et al. (2020) in soft-bottom mussel beds.

Desiccation differed between the interior and edge of the mussel patches only at one site (FA), being lower in the interior. This could be a consequence of increased water holding capacity due to higher accumulation of sediments, and reduced evaporation due to denser mussel packing in the interior of mussel patches. The lack of differences in desiccation at the two other sites could be attributable to different reasons. One of these sites (PC) remains exposed to sea spray and episodic wave splash during the low tide (Olivier et al. 1966; Gutiérrez et al. 2018), which may have maintained homogeneous moisture within mussel patches in spite of structural and sedimentary differences between interior and edges. The remaining site (CO) has a different substrate (consolidated loess; see Material and methods), which absorbs water and might have contributed to equivalent water losses in the interior and edge of mussel patches. It is thus likely that local conditions (e.g., sea spray and wave splash at low tide, substrate type) override any potential differences in desiccation between mussel bed edges and interiors at these sites.

As it concerns to temperature, our measurements conducted at a single site (CO) indicate lack of differences between patch interior and edges. This suggests that heat conduction from mussels to their underlying substrate is similar in the edge and interior of their single-layered patches, notwithstanding their differences in relative mussel size and position relative to the substrate. Because of their predominant position relative to the substrate (i.e., antero-posterior axis parallel to the substrate), mussels in edges show a higher proportion of their surface into contact with the substrate (cf., mussels in interiors with their antero-posterior axis perpendicular to the substrate). An increased surface into contact with the substrate should lead to increased heat conduction (see Mislan and Wethey 2015). Thus, increased temperatures underlying the edge of mussel patches should be expected when considering mussel position alone. However, mussels in the interior of patches are larger than those in edges and retain more sediment in their interstitial space, both of which might contribute to levels of heat conduction similar than those in mussel edges. Caution must be taken, however, when attempting to extrapolate this result and interpretation to sites where mussel bed edges and interiors differ in their capacity to retain water during the low tide (possibly FA), as this may translate into differences in evaporative cooling (see Helmuth 1998).

From the two invertebrate species found in gaps, only the limpet Siphonaria lessonii was affected by edges. The barnacle Balanus glandula was generally found at similar densities in gap edges and interiors. This is

Page $13 / 26$ 
unsurprising as $B$. glandula is a sessile species whose distribution in relation to gap edges would be determined by larval settlement and post settlement survival, both of which are favoured by the presence of small ( $\mathrm{mm}$ scale) roughness elements on the rock surface (see Schubart et al. 1995; Savoya and Schwindt 2010) that occur at random locations within the gaps (i.e., irrespective of distance to the to the mussel patch perimeter). In contrast, $S$. lessonii usually occurred at higher densities in gap edges. This limpet feeds on settling algal spores and sporelings on moist rock surfaces exposed by the ebbing tide but, once these surfaces dry out, they aggregate into relatively moister and thermally benign microhabitats, such as crevices (Olivier and Penchaszadeh 1968; López-Gappa et al. 1996; Aguilera and Navarrete 2011). It is possible that limpets encounter higher humidity and less stressful temperatures by the perimeter of the mussel bed due to shading by the mussels themselves and, possibly, due to the gradual release of interstitial water from the mussel bed. Although we failed to detect differences in desiccation and temperature between gap edges and their interiors, it is still possible that differences occur at a scale smaller than that of our desiccation (5-cm side squared absorbent pads) and temperature measurements (3-cm diameter circular data loggers) but which may still be relevant to limpets (see Strayer et al. 2003; Carroll et al. 2019 for issues of scale and grain when evaluating edge effects). Aggregation itself is also a common behavior in limpets and other intertidal gastropods (e.g., Branch 1981; Garrity 1984; Gallien 1985; Chapman and Underwood 1996; Stafford et al. 2012), which has been postulated to reduce desiccation by enhancing water retention on the rock surface and modifying air circulation over the individuals (see Garrity 1984; Gallien 1985; but see Coleman 2010). Aggregation to conspecifics and mussels at the edge of gaps, together with the exploitation of a potentially moister habitat by the perimeter of the mussel bed, may reduce desiccation in $S$. lessonii and probably account for their higher densities in the edge rather than the interior of gaps.

Understanding species responses to edges in mussel-dominated rocky shores is important as mussel beds are expected to be increasingly fragmented in the future due to patchy dislodgement and mortality caused by storms and heat waves. Indeed, the intensity, frequency, and duration of storms and heat waves in the study region has been increasing over the past decades, and these trends are expected to continue (see Fiore et al. 2009; Dragani et al. 2013; Barros et al. 2015; Rusticucci et al. 2016). Under such scenarios, gaps could be predicted to form more frequently and become more abundant in mussel bed areas, leading to an increased extent of edge habitats. Our findings, however, suggest that invertebrate composition and abundance are not markedly influenced by habitat edges. In the case of the invertebrates inhabiting mussel patches, the general lack of edge effects suggest that species composition would remain largely unaffected by increasing mussel bed fragmentation whereas their overall abundance would decrease proportionally to the overall decrease in mussel cover.

As it concerns to gaps, the observed tendency of limpets. Siphonaria lessonii, toward forming high density aggregations in gap edges suggests putative changes in the biotic composition and functioning of these shores as fragmentation increases. Indeed, if increased availability of edge habitats leads to increased overall density of limpets in rocky shores, then changes could be expected in algal production, composition, and dynamics. At this stage, the nature of such changes is hard to predict since the effects of edge habitats on limpet grazing and the dynamics of algal colonization in gaps will depend on limpet grazing preferences, the extent of their grazing excursions, and the size and perimeter-area ratio of gaps (see Tanaka and Magalhães 2002). Since limpet aggregation in gap edges seems to be a common response to mussel bed fragmentation (see Sousa 1984; Ruiz Sebastián et al. 2002; Tanaka and Magalhães 2002, for examples with other limpet species at other world locations) they are likely important drivers of change in mussel-dominated rocky shore communities facing 
increasing impacts of storms and heat waves. Studies relating the effects of limpet grazing with gap dynamics as influenced by storms and heat waves could help predict changes in such communities in view of impending increments in mussel bed fragmentation.

\section{Declarations}

Acknowledgements We thank Pamela Rivadeneira and José María Cortez Gait for field assistance and Maria Eugenia Becherucci for housing during field trips.

Funding This study was funded by a CONICET grant (Consejo Nacional de Investigaciones Científicas y Técnicas; PICT 2015-2468) to MGP, and a PADI Foundation grant to SAS. SAS, JAG, and SLC are supported by CONICET fellowships. This is a contribution to the programs of Laboratorio de Ecosistemas Costeros y Malacología (MACN) and GrIETA.

Conflict of interest All authors declared that they have no conflict of interest.

Availability of data and material The datasets generated and analyzed during the current study are available from the author on reasonable request.

Code availability Not applicable.

Author Contributions S.A.S., J.L.G. and M.G.P. conceived and designed the study. S.A.S., J.L.G, J.A.G and S.L.C. carried out the field research and sample analysis. S.A.S. was primarily responsible for data analysis and the writing of manuscript drafts. J.L.G, J.A.G, S.L.C and M.G.P. contributed to interpretation of findings and commented on manuscript drafts. All authors read and approved the final manuscript.

Ethical approval All applicable international, national, and/or institutional guidelines for the care and use of animals were followed.

Consent for publication Not applicable.

\section{References}

Aguilera MA, Navarrete SA (2011) Distribution and activity patterns in an intertidal grazer assemblage: influence of temporal and spatial organization on interspecific associations. Mar Ecol Prog Ser 431:119-136. https://doi.org/10.3354/meps09100

Allison PD (2012) Logistic regression using SAS: theory and application. SAS Institute

Amortegui-Torres V, Taborda-Marin A, Blanco JF (2013) Edge effect on a Neritina virginea (Neritimorpha, Neritinidae) population in a black mangrove stand (Magnoliopsida, Avicenniaceae: Avicennia germinans) in the Southern Caribbean. Pan-Am J Aquat Sci 8:68-78.

Arkema KK, Samhouri JF (2019) Living on the edge: Variation in the abundance and demography of a kelp forest epibiont. Diversity 11:120. https://doi.org/10.3390/d11080120 
Arribas LP, Bagur M, Klein E, Penchaszadeh PE, Palomo MG (2013) Geographic distribution of two mussel species and associated assemblages along the northern Argentinean coast. Aquat Biol 18:91-103. https://doi.org/10.3354/ab00495

Arribas LP, Bagur M, Gutiérrez JL, Palomo MG (2015) Matching spatial scales of variation in mussel recruitment and adult densities across southwestern Atlantic rocky shores. J Sea Res 95:16-21. https://doi.org/10.1016/j.seares.2014.10.015

Arribas LP, Gutiérrez JL, Bagur M, Soria SA, Penchaszadeh PE, Palomo MG (2019) Variation in aggregate descriptors of rocky shore communities: a test of synchrony across spatial scales. Mar Biol 166:1-7. https://doi.org/10.1007/s00227-019-3492-6

Bagur M, Gutiérrez JL, Arribas LP, Palomo MG (2016) Complementary influences of co-occurring physical ecosystem engineers on species richness: insights from a Patagonian rocky shore. Biodivers Conserv 25:27872802. https://doi.org/10.1007/s10531-016-1203-x

Barros VR, Boninsegna JA, Camilloni IA, Chidiak M, Magrín GO, Rusticucci M (2015) Climate change in Argentina: trends, projections, impacts and adaptation. Clim Change 6:151-169. https://doi.org/10.1002/wcc.316

Bertolini C, Montgomery WI, O'Connor NE (2020) Edge effects are not linked to key ecological processes in a fragmented biogenic reef. Estuar Coasts 43:708-721. https://doi.org/10.1007/s12237-020-00705-4

Borthagaray Al, Carranza A (2007) Mussels as ecosystem engineers: their contribution to species richness in a rocky littoral community. Acta Oecol 31:243-250. https://doi.org/10.1016/j.actao.2006.10.008

Branch GM (1981) The biology of limpets: physical factors, energy flow, and ecological interactions. Oceangr Mar Biol Ann Rev 19:235-380.

Byrnes JE, Reed DC, Cardinale BJ, Cavanaugh KC, Holbrook SJ, Schmitt RJ (2011) Climate-driven increases in storm frequency simplify kelp forest food webs. Glob Change Biol 17:2513-2524.

https://doi.org/10.1111/j.1365-2486.2011.02409.x

Carroll JM, Keller DA, Furman BT, Stubler AD (2019) Rough around the edges: lessons learned and future directions in marine edge effects studies. Curr Landsc Ecol Rep 4:91-102. https://doi.org/10.1007/s40823-01900043-7

Chapman MG, Underwood AJ (1996) Influences of tidal conditions, temperature and desiccation on patterns of aggregation of the high-shore periwinkle, Littorina unifasciata, in New South Wales, Australia. J Exp Mar Biol Ecol 196:213-237. https://doi.org/10.1016/0022-0981(95)00131-X

Clarke KR (1993) Non-parametric multivariate analyses of changes in community structure. Australian J Ecol 18:117-143. https://doi.org/10.1111/j.1442-9993.1993.tb00438.x

Coleman RA (2010) Limpet aggregation does not alter desiccation in the limpet Cellana tramoserica. J Exp Mar Biol Ecol 386:113-118. https://doi.org/10.1016/j.jembe.2010.02.011

Cribari-Neto F, Zeileis A (2010) Beta regression in R. J Stat Softw 34:1-24. https://doi.org/10.18637/jss.v034.i02 
Dayton PK (1971) Competition, disturbance, and community organization: the provision and subsequent utilization of space in a rocky intertidal community. Ecol Monogr 41:351-389. https://doi.org/10.2307/1948498

Dayton PK (1972) Toward an understanding of community resilience and the potential effects of enrichments to the benthos at McMurdo Sound, Antarctica. In: Proceedings of the colloquium on conservation problems in Antarctica. Allen Press Lawrence, Kansas, USA, pp 81-96

Dragani WC, Martin PB, Alonso G, Codignotto JO, Prario BE, Bacino G (2013) Wind wave climate change: impacts on the littoral processes at the northern Buenos Aires Province Coast, Argentina. Clim Change 121:649-660. https://doi.org/10.1007/s10584-013-0928-8

Ellison AM (2019) Foundation species, non-trophic interactions, and the value of being common. IScience 13:254-268. https://doi.org/10.1016/j.isci.2019.02.020

Ellison AM, Bank MS, Clinton BD, Colburn EA, Elliott K, Ford CR, Foster DR, Kloeppel BD, Knoepp JD, Lovett GM (2005) Loss of foundation species: consequences for the structure and dynamics of forested ecosystems. Front Ecol Environ 3:479-486. https://doi.org/10.1890/1540-9295(2005)003[0479:LOFSCF]2.0.C0;2

Fiore MME, D'Onofrio EE, Pousa JL, Schnack EJ, Bértola GR (2009) Storm surges and coastal impacts at Mar del Plata, Argentina. Cont Shelf Res 29:1643-1649. https://doi.org/10.1016/j.csr.2009.05.004

Gallien WB (1985) The effects of aggregations on water loss in Collisella digitalis. Veliger 28:14-17.

Garrity SD (1984) Some adaptations of gastropods to physical stress on a tropical rocky shore. Ecology 65:559574.

Gestoso I, Arenas F, Rubal M, Veiga P, Peña M, Olabarria C (2013) Shifts from native to non-indigenous mussels: enhanced habitat complexity and its effects on faunal assemblages. Mar Environl Res 90:85-95. https://doi.org/10.1016/j.marenvres.2013.05.015

Gutiérrez JL, Jones CG, Strayer DL, Iribarne 00 (2003) Mollusks as ecosystem engineers: the role of shell production in aquatic habitats. Oikos 101:79-90. https://doi.org/10.1034/j.1600-0706.2003.12322.x

Gutiérrez JL, Jones CG, Byers JE, Arkema KK, Berkenbusch K, Commito JA, Duarte CM, Hacker SD, Lambrinos JG, Hendriks IE, Hogarth PJ, Palomo MG, Wild C (2011) Physical ecosystem engineers and the functioning of estuaries and coasts. In: Heip CHR, Philippart CJM, Middelburg JJ (eds) Volume 7: Functioning of estuaries and coastal ecosystems. In: Wolanski E, McLusky D (eds), Treatise on estuarine and coastal science. Elsevier, Amsterdam. pp. 53-81.

Gutiérrez JL, Palomo MG, Bagur M, Arribas LP, Soria SA (2015) Wave action limits crowding in an intertidal mussel. Mar Ecol Prog Ser 518:153-163. https://doi.org/10.3354/meps11086

Gutiérrez JL, Bagur M, Arribas LP, Palomo MG (2018) Does rock type account for variation in mussel attachment strength? A test with Brachidontes rodriguezii in the southwestern Atlantic. Helgol Mar Res 72:10.

https://doi.org/10.1186/s10152-018-0514-6

Page 17/26 
Gutiérrez JL, Bagur M, Palomo MG (2019) Algal epibionts as co-engineers in mussel beds: effects on abiotic conditions and mobile interstitial invertebrates. Diversity 11:17. https://doi.org/10.3390/d11020017

Hammer $\varnothing$, Harper DA, Ryan PD (2001) PAST: Paleontological statistics software package for education and data analysis. Palaeontol Electron 4:9.

Harley CD, Randall Hughes A, Hultgren KM, Miner BG, Sorte CJ, Thornber CS, Rodriguez LF, Tomanek L, Williams SL (2006) The impacts of climate change in coastal marine systems. Ecol Lett 9:228-241.

https://doi.org/10.1111/j.1461-0248.2005.00871.x

Helmuth BS (1998) Intertidal mussel microclimates: predicting the body temperature of a sessile invertebrate. Ecol Monogr 68:51-74. https://doi.org/10.1890/0012-9615(1998)068[0051:IMMPTB]2.0.C0;2

Jones CG, Lawton JH, Shachak M (1994) Organisms as ecosystem engineers. Oikos 69: 373-386.

https://doi.org/10.2307/3545850

Jones CG, Lawton JH, Shachak M (1997) Positive and negative effects of organisms as physical ecosystem engineers. Ecology 78:1946-1957. https://doi.org/10.1890/0012-9658(1997)078[1946:PANEOO]2.0.CO;2

Jurgens LJ, Gaylord B (2016) Edge effects reverse facilitation by a widespread foundation species. Sci Rep 6:110. https://doi.org/10.1038/srep37573

Lenth R (2019) emmeans: estimated marginal means, aka least-squares means. R package v. 1.3. 4.

López-Gappa J, Tablado A, Magaldi N (1996) Observations on activity pattern and resting site fidelity in the pulmonate limpet Siphonaria lessoni. Thalassas 12:27-36.

Mislan KAS, Wethey DS (2015) A biophysical basis for patchy mortality during heat waves. Ecology 96:902-907. https://doi.org/10.1890/14-1219.1

Oliver EC, Donat MG, Burrows MT, Moore PJ, Smale DA, Alexander LV, Benthuysen JA, Feng M, Gupta AS, Hobday AJ (2018) Longer and more frequent marine heatwaves over the past century. Nat Commun 9:1-12.

https://doi.org/10.1038/s41467-018-03732-9

Olivier SR, Penchaszadeh PE (1968) Observaciones sobre la ecología y biología de Siphonaria (Pachysiphonaria) lessoni (Blainville, 1824) (Gastropoda, Siphonariidae) en el litoral rocoso de Mar del Plata (Bs. As.). Cah Biol Mar 9:469-491.

Olivier SR, Escofet A, Orensanz JM, Pezzani SE, Turro AM, Turro ME (1966) Contribución al conocimiento de las comunidades bénticas de Mar del Plata. Anales CIC 7:185-206

Paine RT (1966) Food web complexity and species diversity. Am Natt 100:65-75.

https://doi.org/10.1086/282400

Paine RT, Levin SA (1981) Intertidal landscapes: disturbance and the dynamics of pattern. Ecol Monogr 51:145178. https://doi.org/10.2307/2937261 
Palomo MG, People J, Chapman MG, Underwood AJ (2007) Separating the effects of physical and biological aspects of mussel beds on their associated assemblages. Mar Ecol Prog Ser 344:131-142.

https://doi.org/10.3354/meps07002

Palomo MG, Bagur M, Quiroga M, Soria S, Bugnot A (2016) Ecological impacts of two non-indigenous macroalgae on an urban rocky intertidal shore. Mar Biol 163:178. https://doi.org/10.1007/s00227-016-2951-6

Penchaszadeh PE (1973) Ecología de la comunidad del mejillín (Brachydontes rodriguezi d'Orb.) en el mediolitoral rocoso de Mar del Plata (Argentina): el proceso de recolonización. Physis A 32:51-64.

Penchaszadeh PE, Scelzo MA, Palomo MG, Cuevas M, Cledón M (2007) A review of the intertidal rocky shore community at Mar del Plata (Argentina) characterized by the mussel Brachidontes rodriguezii (d'Orbigny, 1846). Publ Seto Mar Biol Lab 8:115-123.

Pinheiro J, Bates D, DebRoy S, Sarkar D (2019) R Core Team. 2019. nlme: linear and nonlinear mixed effects models. $\mathrm{R}$ package version 3.1-141.

R Core Team (2020) R: a language and environment for statistical computing. 2020. R Foundation for Statistical Computing, Vienna, Austria

Ruiz Sebastián CR, Steffani CN, Branch GM (2002) Homing and movement patterns of a South African limpet Scutellastra argenvillei in an area invaded by an alien mussel Mytilus galloprovincialis. Mar Ecol Prog Ser 243:111-122. https://doi.org/10.3354/meps243111

Rusticucci M, Kyselỳ J, Almeira G, Lhotka O (2016) Long-term variability of heat waves in Argentina and recurrence probability of the severe 2008 heat wave in Buenos Aires. Theor Appl Climatol 124:679-689. https://doi.org/10.1007/s00704-015-1445-7

Savoya V, Schwindt E (2010) Effect of the substratum in the recruitment and survival of the introduced barnacle Balanus glandula (Darwin 1854) in Patagonia, Argentina. J Exp Mar Biol Ecol 382:125-130.

https://doi.org/10.1016/j.jembe.2009.10.012

Schubart CD, Basch LV, Miyasato G (1995) Recruitment of Balanus glandula Darwin (Crustacea: Cirripedia) into empty barnacle tests and its ecological consequences. J Exp Mar Biol Ecol 186:143-181.

https://doi.org/10.1016/0022-0981(94)00142-Z

Silliman BR, Bertness MD, Altieri AH, Griffin JN, Bazterrica MC, Hidalgo FJ, Crain CM, Reyna MV (2011) Wholecommunity facilitation regulates biodiversity on Patagonian rocky shores. PLoS ONE 6:e24502. https://doi.org/10.1371/journal.pone.0024502

Sousa WP (1984) Intertidal mosaics: patch size, propagule availability, and spatially variable patterns of succession. Ecology 65:1918-1935. https://doi.org/10.2307/1937789

Stafford R, Davies MS, Williams GA (2012) Cheats in a cooperative behaviour? Behavioural differences and breakdown of cooperative behaviour in aggregating, intertidal littorinids (Mollusca. Mar Ecol 33:66-74. https://doi.org/10.1111/j.1439-0485.2011.00474.x

Page 19/26 
Strayer DL, Power ME, Fagan WF, Pickett STA, Belnap J (2003) A classification of ecological boundaries.

BioScience 53:723-729. https://doi.org/10.1641/0006-3568(2003)053[0723:ACOEB]2.0.CO;2

Suchanek TH (1985) Mussels and their role in structuring rocky shore communities. In: Moore PG, Seed R (eds) The ecology of rocky coasts. Hodder \& Stoughton Press, London, pp. 70-96

Tanaka MO, Magalhães CA (2002) Edge effects and succession dynamics in Brachidontes mussel beds. Mar Ecol Prog Ser 237:151-158. https://doi.org/10.3354/meps237151

Tanner JE (2005) Edge effects on fauna in fragmented seagrass meadows. Austral Ecol 30:210-218. https://doi.org/10.1111/j.1442-9993.2005.01438.x

Tokeshi M, Romero L (1995) Filling a gap: dynamics of space occupancy on a mussel-dominated subtropical rocky shore. Mar Ecol Prog Ser 167-176. https://doi.org/10.3354/meps119167

Underwood AJ, Chapman MG, Cole VJ, Palomo MG (2008) Numbers and density of species as measures of biodiversity on rocky shores along the coast of New South Wales. J Exp Mar Biol Ecol 366:175-183. https://doi.org/10.1016/j.jembe.2008.07.022

Venables WN, Ripley BD (2002) Random and mixed effects. In: Modern applied statistics with S. Springer, New York, pp 271-300

\section{Figures}

\section{Mussel Patch}

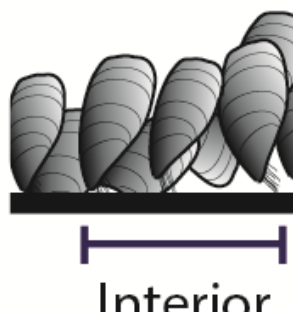

\section{Figure 1}

Positions sampled at each site. Blue and orange lines represent the positions sampled within mussel patches and gaps, respectively

\section{Gap}

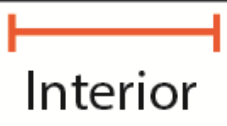



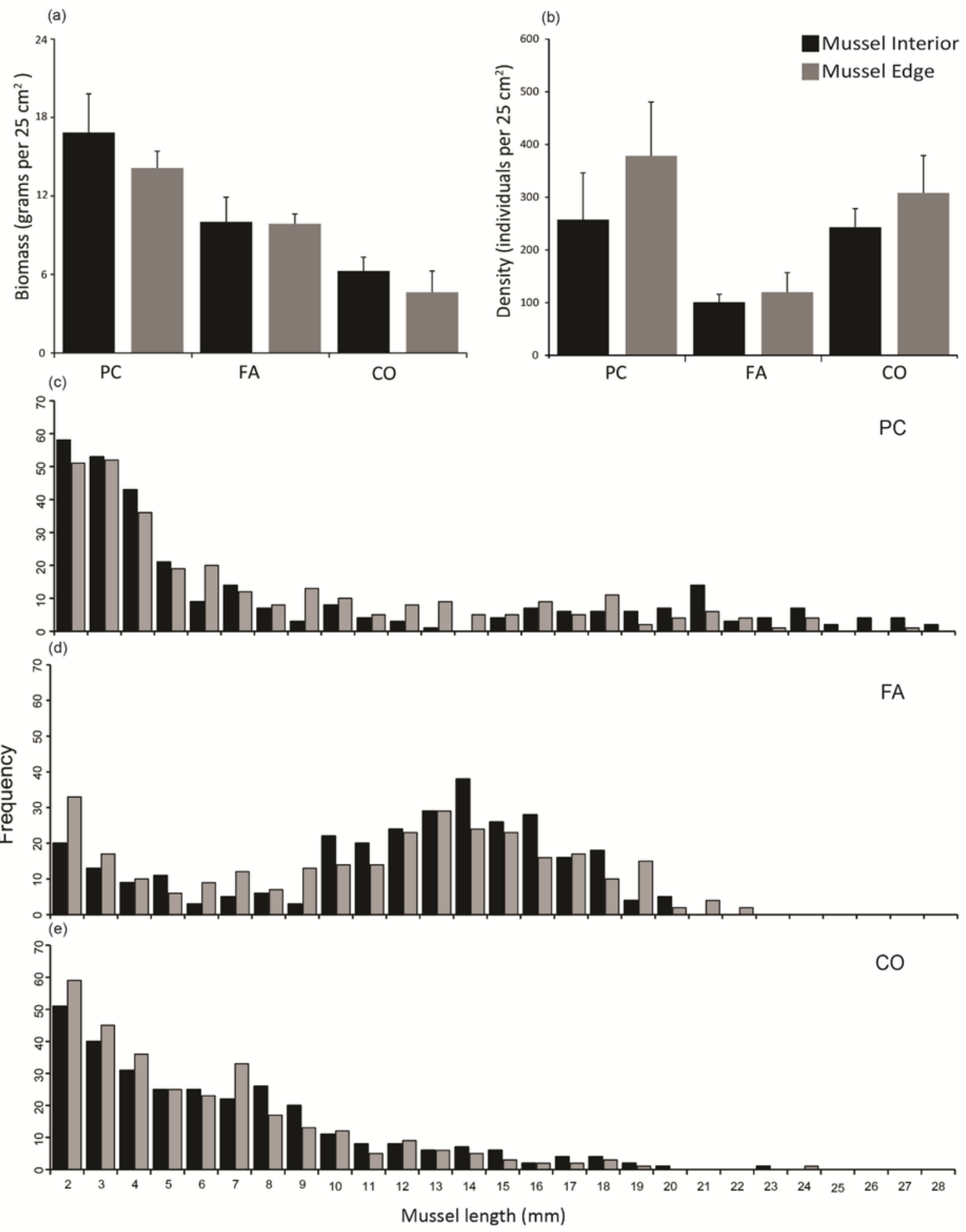

Figure 2

$(a, b)$ Mean (SD) biomass (a) and density (b) of mussels in the interior and edge of patches. In both cases, differences were significant across sites (Main effect: $p<0.05)$. (c, d, e) Size frequency distributions of mussels in the interior and edge of mussel patches at Playa Chica (c, PC), Faro (d, FA), and Copacabana (e, CO). Significant differences in size distributions were found in all sites $(p<0.05)$ 


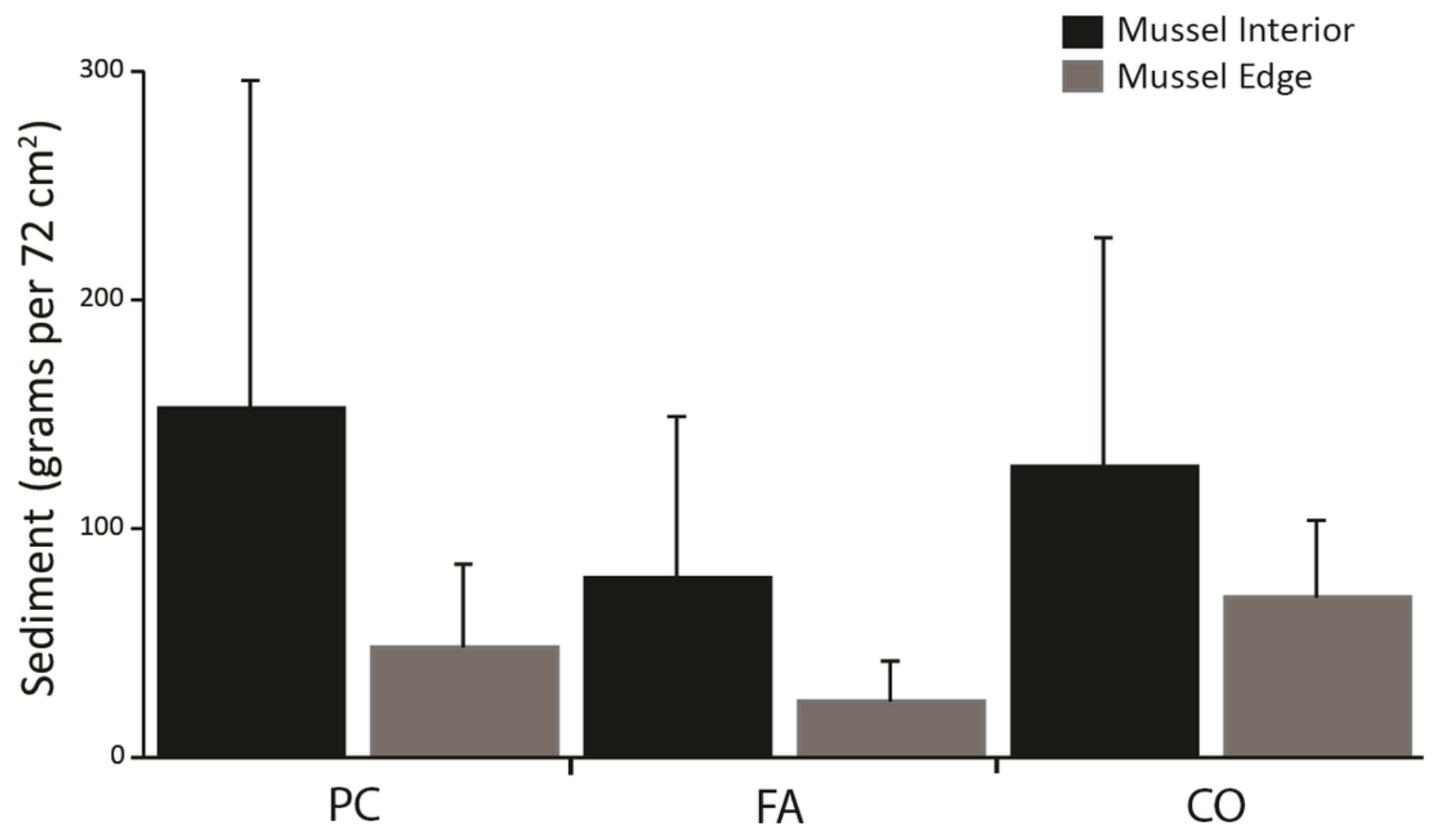

Figure 3

Mean (SD) weight of sediment retained in the interior and edge of mussel patches at three sites (PC: Playa Chica, FA: Faro, Co: Copacabana). Differences were significant across sites (Main effect: $p<0.05$ )

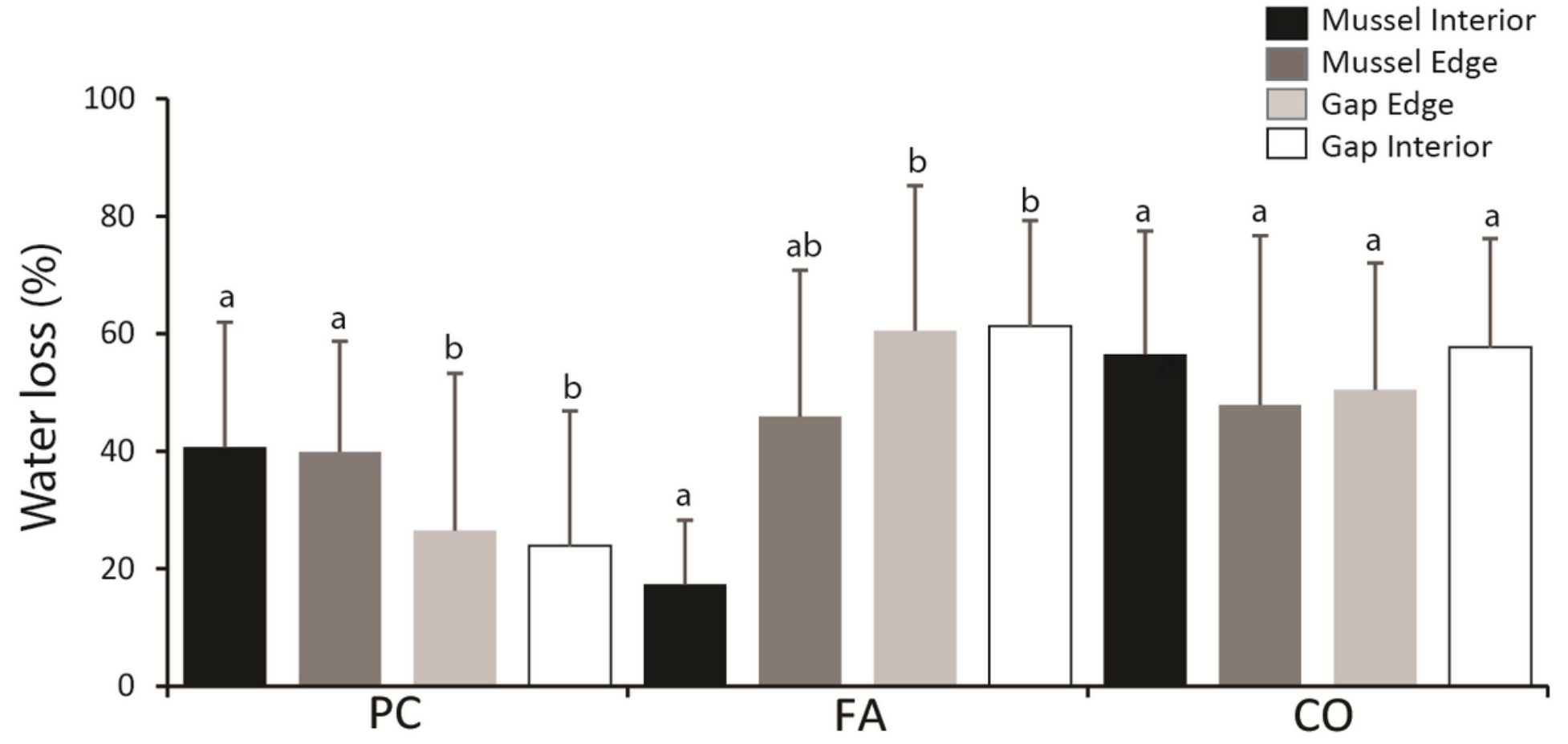

Figure 5 
Mean (SD) desiccation (as percent water loss from absorbent cloth pads) in the interior and edge of mussel patches and gaps. Different letters above bars indicate significant differences within each site $(p<0.05)$

(a)

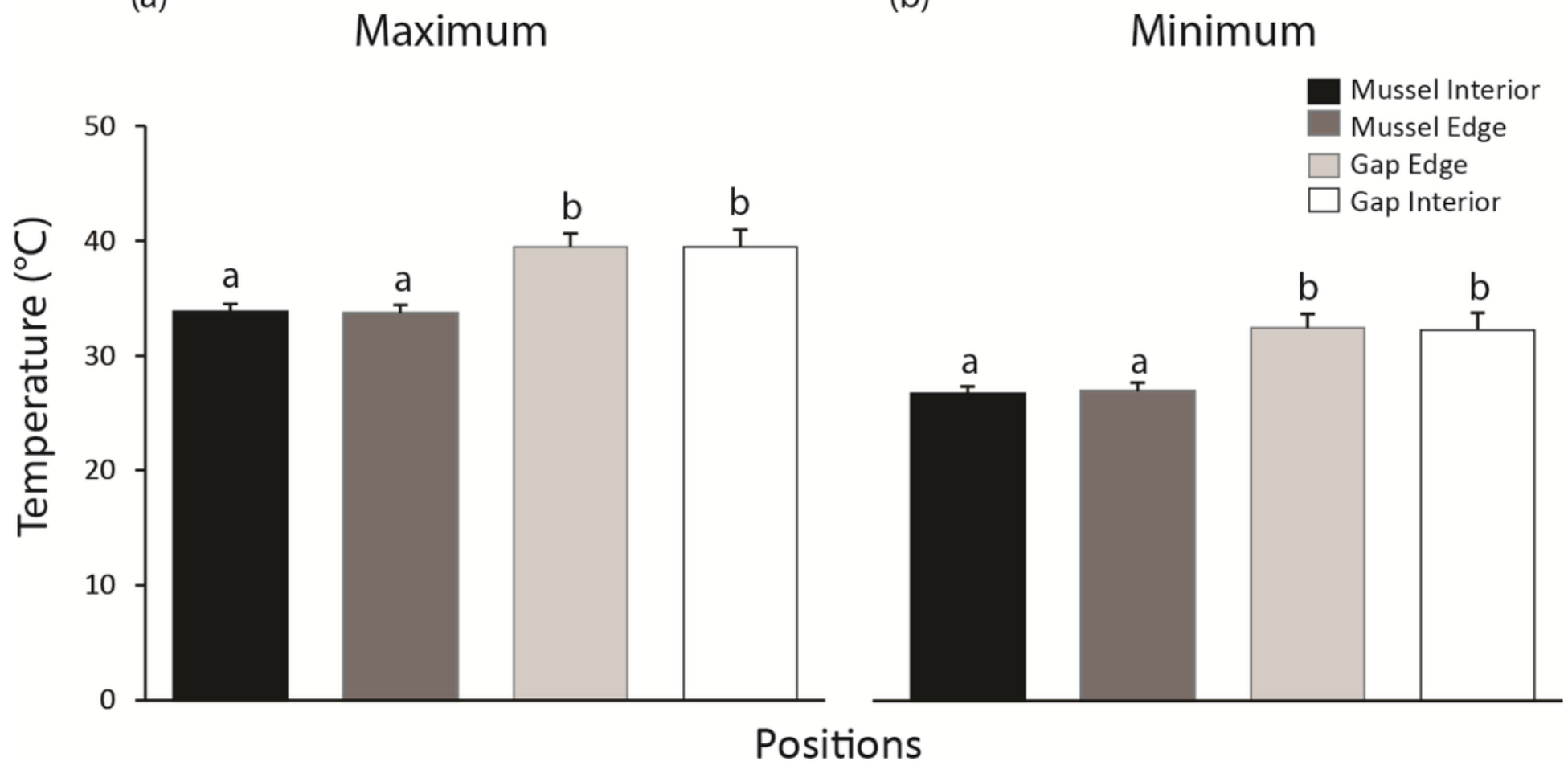

\section{Figure 6}

Mean (SD) maximum (a) and minimum (b) temperatures recorded in the interior and edge of mussel patches and gaps in Copacabana. Different letters above bars indicate significant difference 

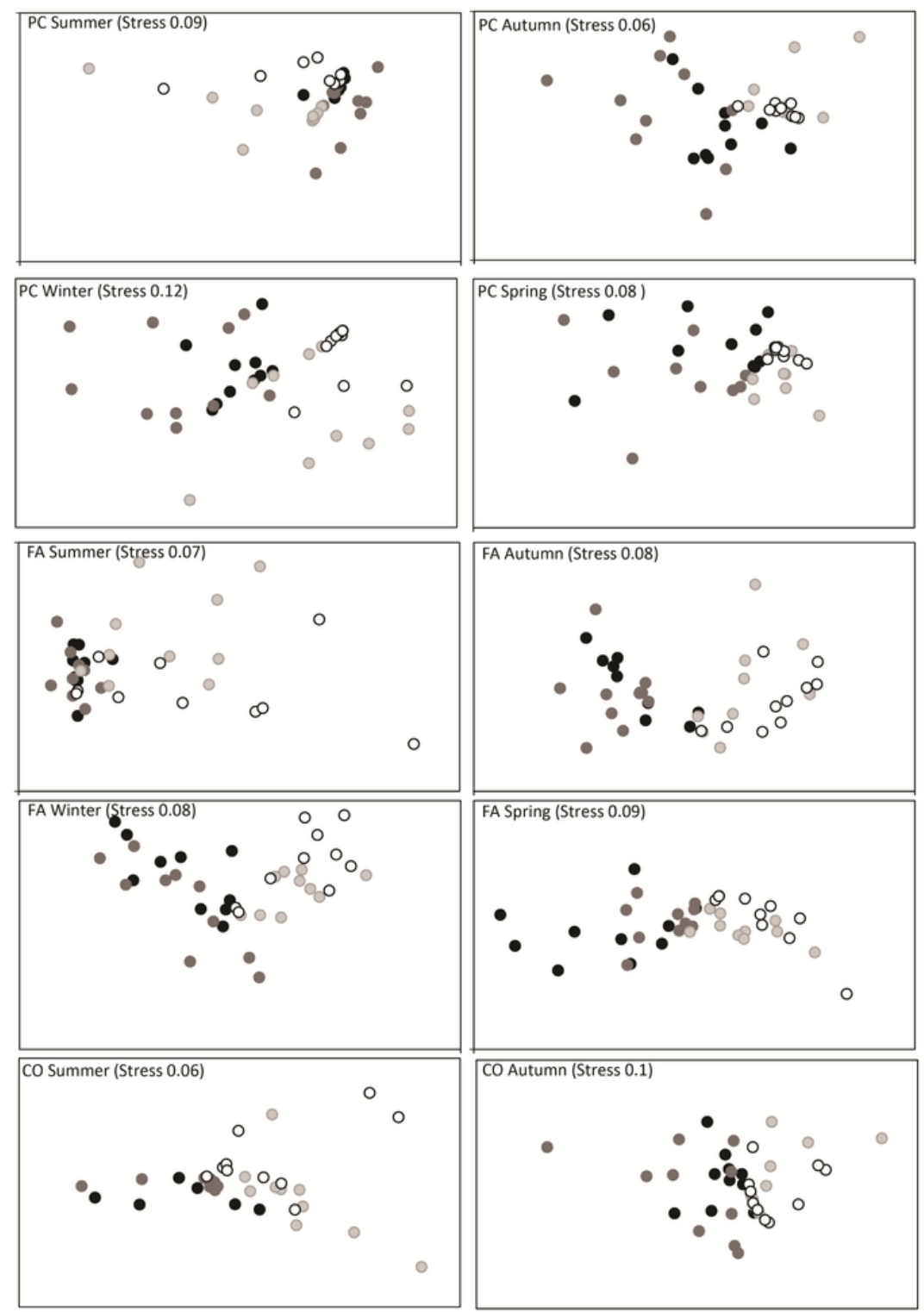

CO Autumn (Stress 0.1)
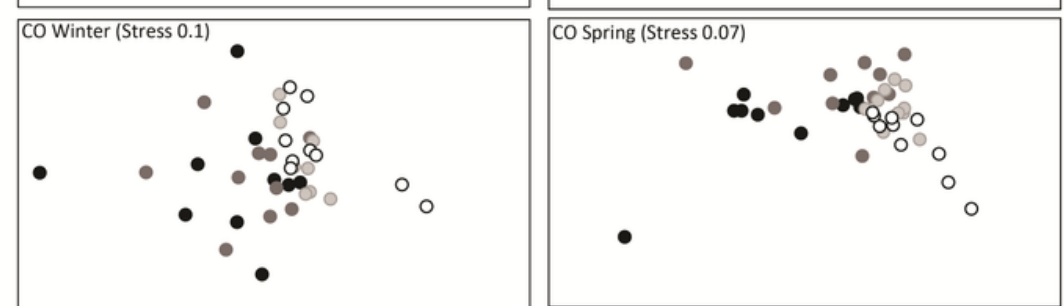

- Mussel Interior - Mussel Edge $\bigcirc$ Gap Edge $\bigcirc$ Gap Interior

\section{Figure 7}

Non-metric multidimensional scaling plot comparing species assemblages between Positions (interior and edge of mussel patches and gaps) at each Site (PC: Playa Chica, FA: Faro, CO: Copacabana) and Seasons (Summer, Autumn, Winter, Spring) 


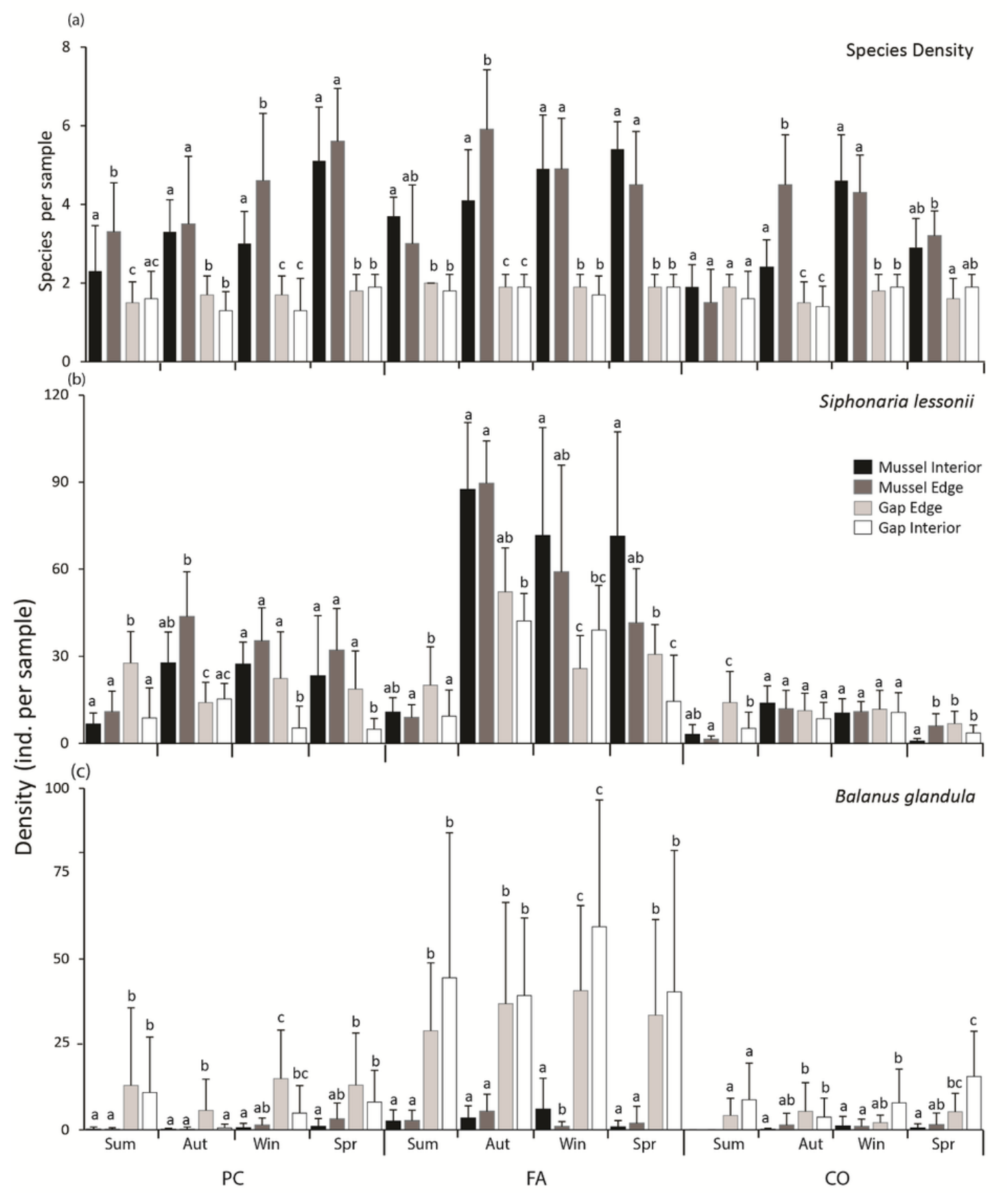

Figure 8

Mean (SD) species density (i.e., number of species per sample) (a), and mean (SD) density of two common species: the pulmonate limpet Siphonaria lessonii (b) and the barnacle Balanus glandula (c), in the interior and edge of mussel patches and gaps at each Site (PC: Playa Chica, FA: Faro, CO: Copacabana) and Season (Sum: Summer, Aut: Autumn, Win: Winter and Spr: Spring). Different letters above bars indicate significant differences at each Site and Season 
(a)

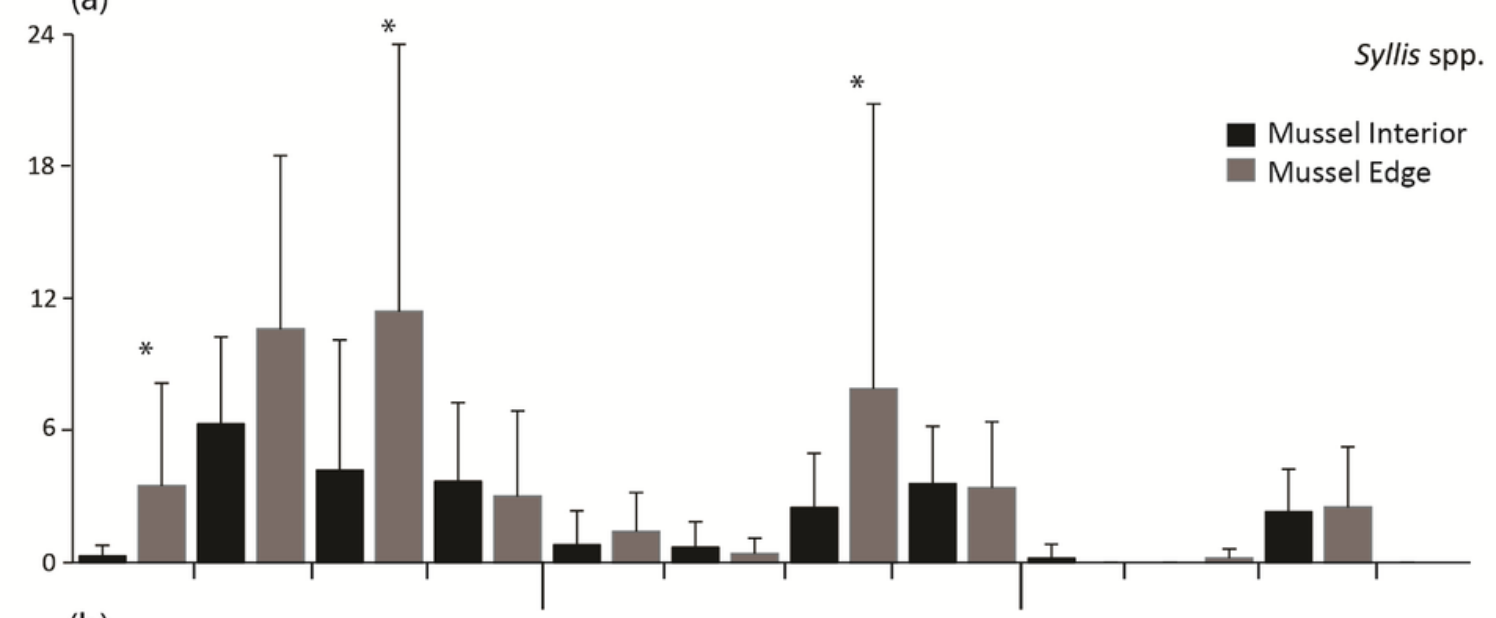

(b)
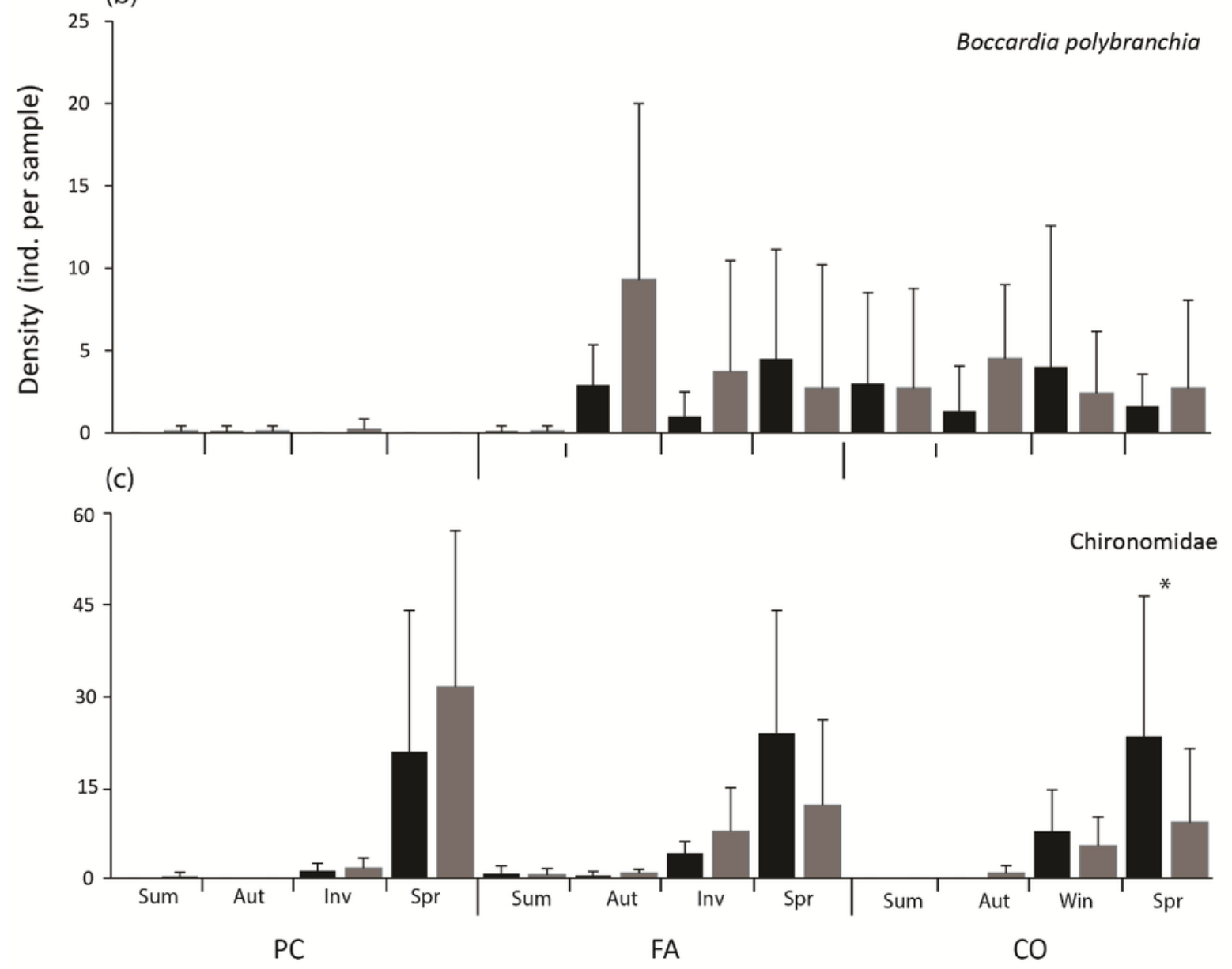

Figure 9

Mean (SD) density of three common taxa: the polychaetes Syllis spp. (a) and Boccardia polybranchia (b), and larvae-pupae of Chironomids (c) in the interior and edge of mussel beds at each Site (PC: Playa Chica, FA: Faro, CO: Copacabana) and Season (Sum: Summer, Aut: Autumn, Win: Winter and Spr: Spring). Asterisks above bars indicate significant differences between interior and edges at a given Site and Season 